\title{
Learning with patience
}

\section{Abi Berger}

General Practitioner, London, UK

Correspondence to

Dr Abi Berger c/o

journal@fsrh.org

Received 27 October 2016

Accepted 9 November 2016
CrossMark

To cite: Berger A. J Fam Plann Reprod Health Care 2017;43:76.
"Am I pregnant?" she asked nervously. Of course I had no idea but it seemed unlikely from her history. She was determined not to take a test and just wanted me to say "no". I couldn't. "Well maybe it's just my hormones?" she asked again, hopefully. I could give her no certainty about that either. She is a 32-year-old full-time city worker holding down an intensely demanding job. She looked exhausted and exuded nervous energy. There was plenty of life stuff that might be causing her erratic periods and tiredness, but nothing she wanted to examine, as long as I was sure she couldn't blame her hormones.

Next up was a 23-year-old sedentary secretary with mild facial acne and a degree of obesity. She was sure she had polycystic ovarian syndrome because she'd read about it. But her hormone levels were normal and she wasn't happy about it. She wants to see a specialist.

As for myself, I'm off work for a month - I've taken unpaid leave before cutting back to a more part-time doctoring role and I'm about to embark on something new and nurturing for myself. It feels like a much needed fresh start. I find I'm now doing everything more slowly, am sleeping much more solidly than I have for months (possibly years?) and am gaining weight (happily in my case). I'm still using hormone replacement therapy but I feel so much better in myself, having unwound more fully than I have done in years that I'm thinking of stopping it. I guess I could question my hormones, but the reality is I'm simply recovering from a chronic level of burnout. Some would say I'd been 'overadrenalised' and now normal service is gradually being resumed. There are no blood tests for me, but there is a lesson about better self-monitoring - and better self-care - being the order of the day. And permission to make changes, so that I don't revisit this state again.
But how to persuade others that looking inwards and self-examination might be more useful tools than blood tests and more invasive procedures? Or that a significant change to lifestyle might lead more successfully and sustainably to feeling well? A quick fix is far more desirable to most than the challenge of selfcare. We seem to be living in an age and a society where the norm is to override any useful signals our bodies flash up to try to grab our attention, and to push through regardless.

And it's not just women. I've had consultations with stressed-out men recently, some of whom have stopped short of complete despair, but only just. One had to be signed off sick for weeks before his night sweats and diarrhoea resolved. $\mathrm{He}$ put off seeking medical help because he thought he was "just coming down with something" although he admitted whatever he was coming down with, never actually materialised. His tests were all normal.

As he is now reluctantly coming to terms with the fact that his symptoms were stress-induced, he's given himself permission to look at how he's been living and working over the last 6 months - and it's not a pretty sight. He tells me shamefacedly that he thinks he's had a "break-down". I quietly urge him to consider it a "break-through", especially as he's now making plans to take voluntary redundancy. He smiles for the first time in weeks. He prefers that diagnosis.

As I sit across the desk from him, looking the professional part but feeling a bit of a fraud, I remind myself that not only does it "take one to know one", but that we teach "what we most need to learn". My extended leave is about to start, and I smile inwardly for the first time in weeks.

Competing interests None declared.

Provenance and peer review Commissioned; internally peer reviewed. 